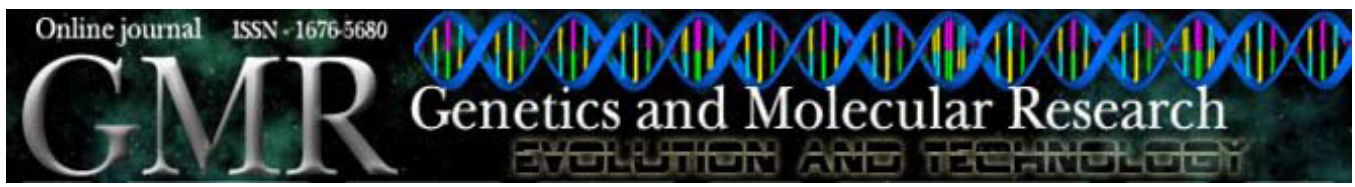

\title{
Relationship between structural and biochemical characteristics and texture of corn grains
}

\author{
R.C. Pereira1 ${ }^{1}$, L.C. Davide ${ }^{1}$, C.A. Pedrozo ${ }^{2}$, N.P. Carneiro ${ }^{3}$, \\ I.R.P. Souza ${ }^{3}$ and E. Paiva ${ }^{3}$ \\ ${ }^{1}$ Departamento de Biologia, Universidade Federal de Lavras, Lavras, MG, Brasil \\ ${ }^{2}$ Universidade Federal de Viçosa, Viçosa, MG, Brasil \\ ${ }^{3}$ Embrapa Milho e Sorgo, Sete Lagoas, MG, Brasil \\ Corresponding author: L.C. Davide \\ E-mail: lisete.ufla@gmail.com
}

Genet. Mol. Res. 7 (2): 498-508 (2008)

Received February 13, 2008

Accepted May 15, 2008

Published June 10, 2008

\begin{abstract}
The texture of corn grains is a fundamental characteristic for the industry as well as for grain producers and processors. To further understand the mechanisms involved in grain hardness, contrasting corn cultivars for grain hardness and protein quality were evaluated. The cultivars were Cateto $\mathrm{L}_{237 / 67}$ (hard endosperm and low protein value), QPM BR 451 (semi-hard endosperm and high protein value); Bolivia-2 (floury endosperm and low protein value), and Opaque-2 (floury endosperm and high protein value). Evaluations were carried out at 10, 20,30, 40, 50, and 60 days after pollination in developing corn grains and in the mature grain. In developing grains, evaluation consisted in the determination of the area, percentage of starch granules, distribution of starch granules, and protein bodies in the endosperm. In mature corn grains, the parameters evaluated were: density, percentage of total proteins, levels of lysine and tryptophan, and banding pattern of zeins. The results
\end{abstract}


indicate that the higher physical resistance of corn grains from the cultivars analyzed is influenced by the high percentage of total proteins, high synthesis of 27-kDa zeins, presence of protein bodies, and perfect organization of starch granules in the endosperm, independent of their sizes.

Key words: Starch granules; Protein bodies; Zein; Endosperm; Corn

\section{INTRODUCTION}

Corn is of great importance in the human diet and animal feed in many parts of the world, but the deficiency in essential amino acids, particularly lysine and tryptophan, limits its nutritional value. The discovery of mutants, known as Opaque (Mertz et al., 1964) capable of modifying the protein value of corn grains by increasing lysine and tryptophan content, gave rise to expectations of improving corn protein quality. However, the commercial utilization of Opaque genotypes has been limited by a series of undesirable agronomical features such as decrease in storage protein levels in the endosperm, decrease in grain density, increase in susceptibility to attacks by pests and diseases, and decrease in productivity (Ortega and Bates, 1983; Villegas et al., 1992; Toro, 2001).

Breeding programs, through backcrossing and recurrent selection, have developed varieties with high protein value and favorable texture (Vasal et al., 1980; Prasanna, et al., 2001), named "Quality Protein Maize" or QPM. Such varieties, however, are unstable with regard to endosperm texture (Lopes, 1989).

The endosperm of corn grains is known to have a complex mixture of starch granules and protein bodies. According to Duvick (1961), the endosperm physical structure depends on the type of interaction between these compounds, and storage proteins play an important role in the physical structure of the mature grain. Variations in the grain physical structure have been associated with differences in the packing degree of the cellular compounds, thickness of the cell wall, size of the cells in the endosperm storage parenchyma, thickness of the proteinaceous matrix in contact with starch granules, and strength of adhesion between the proteinaceous matrix and starch granules (Simmonds et al., 1973; Abdelrahman and Hoseney, 1984; Kriz, 1987).

In floury-texture corn and sorghum grains, starch granules and protein bodies are arranged in a disorganized manner in the endosperm (Robutti et al., 1974; Cagampang et al., 1985; Kriz, 1987; Wall and Bietz, 1987). In vitreous grains, packing of starch granules is more organized, and the intergranular spaces are perfectly filled (Simmonds et al., 1973; Glenn et al., 1991; Gibbon et al., 2003; Gibbon and Larkins, 2005). Normally, storage proteins are responsible for the association between starch grains and endosperm matrix proteins, influencing thus the grain hardness (Abdelrahman and Hoseney, 1984; Hoseney, 1987; Dombrink-Kurtzman and Bietz, 1993).

The composition and arrangement of storage proteins alter the texture and, consequently, the physical structure of the endosperm (Dombrink-Kurtzman and Bietz, 1993). Regions of hard endosperm in the corn grain have a higher alpha- and gamma-zein content (Paiva et al., 1991; Dombrink-Kurtzman and Bietz, 1993). There is evidence that 27-kDa gamma-zein shows marked participation in the formation of vitreous endosperm, since there 
is an increase in this zein in QPM genotypes (vitreous), when compared with floury Opaque-2 genotypes (Wallace et al., 1990). Such increase in zein content in protein bodies leads to an increase in their diameter, which probably provides better packing of starch granules in QPM endosperm (Bostwick et al., 1995).

The texture of corn grains is a fundamental characteristic for grain producers and processors, as it is related to density, susceptibility to attacks by pests and diseases, digestibility and lysis during processing and storage procedures (Pomeranz et al., 1984; Correa et al., 2002; Johnson et al., 2002). Studies aimed at elucidating the factors that affect corn grain texture using tropical genotypes are important for breeding programs whose purpose is to develop cultivars with grains of high protein value and favorable texture.

Therefore, the aims of the current study were to perform biochemical and structural characterization of grains from contrasting corn cultivars for protein content and quality and endosperm texture and to determine the relationship between such characteristics and grain hardness.

\section{MATERIAL AND METHODS}

Field experiments were carried out in Lavras, south region of Minas Gerais State Brazil, at $910 \mathrm{~m}$ altitude, $21^{\circ} 45^{\prime} \mathrm{S}$ latitude and $45^{\circ} 00^{\prime} \mathrm{W}$ longitude.

Four contrasting cultivars were analyzed for protein content and quality, endosperm texture, from the Germplasm Bank of the National Center on Corn and Sorghum Research (Centro Nacional de Pesquisa Milho e Sorgo - EMBRAPA), located at Sete Lagoas, Minas Gerais State, Brazil. Hard and semi-hard endosperms were respectively represented by $\mathrm{Ca}-$ teto $\mathrm{L}_{237 / 67}$ (of low protein value) and QPM BR 451 (of high protein value); soft endosperm was represented by Opaque-2 (of high protein value) and by the Indian cultivar Bolivia-2 (of low protein value). Developing corn grains were evaluated for area of starch granules, percentage of starch, arrangement of starch granules, and protein bodies in the endosperm. Mature grain was evaluated for density, total protein content, lysine and tryptophan content, and electrophoretic profile of storage proteins. Harvesting was carried out at 10, 20, $30,40,50$, and 60 days after pollination (DAP).

Corn grains from the median portion of 5 years from each cultivar were frozen in liquid nitrogen and evaluated for starch granule area and percentage of starch.

Starch granule area was measured based on 3 replications, with 5 slides analyzed per replication, resulting in a total of 100 evaluated starch granules per replication. Slides were analyzed using an Olympus BX60 photomicroscope, and the granular area was measured using the software Jandel Sigma Scan ${ }^{\circledR}$ Pro, version 2.0.

The percentage of starch in developing endosperm was assessed according to the method of Smogyi-Nelson, proposed by Nelson (1994), using 4 replications.

The arrangement of starch granules and protein bodies in the endosperm was determined using scanning electron microscopy (SEM) and light microscopy. For such analyses, corn grains were fixed in $2.5 \%$ glutaraldehyde and $4 \%$ formaldehyde, both prepared in $50 \mathrm{mM}$ phosphate buffer, pH 7.2 (Lending and Larkins, 1989). For SEM analysis of starch granule arrangement in the endosperm, the usual procedures for biological samples were adopted. To determine the format of starch granules, alcoholic suspensions were applied onto stubs, covered with gold and evaluated using SEM.

For light microscopy analysis, $2 \mu \mathrm{m}$-thick sections were obtained using a micro- 
tome. Starch granules were stained with $0.05 \%$ basic fuchsin, which was prepared in 25 $\mathrm{mM} \mathrm{KH} \mathrm{PO}_{4} / \mathrm{Na}_{2} \mathrm{HPO}_{4}, \mathrm{pH} 7.0$, and contained 5\% ethanol. Protein bodies were stained with a stain mixture $(0.13 \%$ methylene blue, $0.02 \%$ azure II, $10 \%$ glycerol, and $10 \%$ meth$\mathrm{yl}$ alcohol, all prepared in distilled water). The images were captured using an Optronics ${ }^{\circledR}$ micro-camera coupled to an Olympus BX60 photomicroscope and transferred to a microcomputer using the software Optronics ${ }^{\circledR}$, or photographed at 40X magnification.

Statistical analysis was carried out for area of starch granules $\left(\mu \mathrm{m}^{2}\right)$ and percentage of starch in the grains. The experimental design was completely randomized in a parcel scheme subdivided in time, and the number of replications varied with the characteristic evaluated.

The effect of all 4 cultivars was determined in the parcels, and the effect of the endosperm development stages was determined in the subparcels. Analyses were carried out using the statistical program SISVAR, developed by Ferreira (2000).

The density of mature corn grains was determined according to the method proposed by Kniep and Mason (1989), and the percentage of protein was assessed by the Kjedahl method (Association of Official Analytical Chemistry, 2000).

Total protein content and tryptophan and lysine content were determined according to the colorimetric method for rapid analysis of tryptophan, described by Opienska-Blsauth et al. and modified by Hernandez and Bates (1969).

A completely randomized design was used for all characteristics evaluated in the mature grain, with 5 replications for density and 4 replications for the remaining characteristics. Analyses of variance were carried out using the statistical program SISVAR, developed by Ferreira (2000).

Electrophoretic analysis of storage proteins in the mature grain was done following the method used by Coelho (1997).

\section{RESULTS AND DISCUSSION}

Density values of the cultivars evaluated varied from 1.06 to 1.32 , and the lowest values were observed in soft-textured corn grains (Table 1). Total protein content behaved similarly. Cultivars with hard- and semi-hard-textured corn grains, QPM BR 451 and Cateto $\mathrm{L}_{237 / 67}$, respectively, showed the highest density and total protein values (Table 1). However, lysine and tryptophan levels were higher in Opaque-2 and QPM BR 451, which have grains of contrasting textures and high protein value. Bolivia-2, although demonstrating a floury texture and low protein value, showed intermediate levels of these amino acids. These results agree with those of other studies indicating that Opaque-2 mutant and the modified genotype have higher lysine and tryptophan content (Table 1).

Table 1. Mean density values, percentage of proteins (PT), and levels of tryptophan (TRP) and lysine (LYS) in corn grains from the cultivars Bolivia-2, Cateto $\mathrm{L}_{237 / 67}$, Opaque-2, and QPM BR 451.

\begin{tabular}{lcccc}
\hline Cultivar & Density & PT & TRP & LYS \\
\hline Bolivia-2 & $1.07^{\mathrm{c}}$ & $9.31^{\mathrm{c}}$ & $0.52^{\mathrm{c}}$ & $2.49^{\mathrm{c}}$ \\
Cateto L 237767 $_{\text {Opaque-2 }}^{1.32^{\mathrm{a}}}$ & $1.06^{\mathrm{c}}$ & $11.75^{\mathrm{a}}$ & $0.38^{\mathrm{d}}$ & $1.91^{\mathrm{d}}$ \\
QPM BR 451 & $1.19^{\mathrm{b}}$ & $7.94^{\mathrm{d}}$ & $0.85^{\mathrm{a}}$ & $3.83^{\mathrm{a}}$ \\
\hline
\end{tabular}

Means followed by different letters in the same column are significantly different according to the Scott-Knott test $(\mathrm{P} \leq 0.05)$. 
Cateto $\mathrm{L}_{237 / 67}$ and Bolivia-2, of low protein value and with hard and floury endosperm, respectively, had the largest starch granules at all development stages of the corn grain, except for 20 DAP (Table 2 and Figure 1), when Bolivia-2 had the largest granular area of all evaluated cultivars including Cateto $\mathrm{L}_{237 / 67}$.

Table 2. Mean area values $\left(\mu \mathrm{m}^{2}\right)$ for starch granules from the cultivars Bolivia-2, Cateto $\mathrm{L}_{237 / 67}$, Opaque-2, and
QPM BR 451, at different stages of endosperm development.
\begin{tabular}{lccccccr}
\hline Cultivar & \multicolumn{7}{c}{ Days after pollination } \\
\cline { 2 - 8 } & 10 & 20 & 30 & 40 & 50 & 60 & Mean \\
\hline Bolivia -2 & $3.46^{\mathrm{b}}$ & $11.39^{\mathrm{a}}$ & $11.82^{\mathrm{a}}$ & $14.80^{\mathrm{a}}$ & $14.17^{\mathrm{a}}$ & $16.91^{\mathrm{b}}$ & $12.09^{\mathrm{b}}$ \\
Cateto L $_{23767}$ & $6.76^{\mathrm{a}}$ & $9.30^{\mathrm{b}}$ & $13.44^{\mathrm{a}}$ & $16.89^{\mathrm{a}}$ & $16.44^{\mathrm{a}}$ & $20.77^{\mathrm{a}}$ & $13.94^{\mathrm{a}}$ \\
Opaque-2 & $4.34^{\mathrm{b}}$ & $8.67^{\mathrm{b}}$ & $10.60^{\mathrm{b}}$ & $10.72^{\mathrm{b}}$ & $11.60^{\mathrm{b}}$ & $13.53^{\mathrm{c}}$ & $9.91^{\mathrm{c}}$ \\
QPM Br 451 & $3.81^{\mathrm{b}}$ & $7.71^{\mathrm{b}}$ & $9.90^{\mathrm{b}}$ & $11.60^{\mathrm{b}}$ & $11.12^{\mathrm{b}}$ & $13.14^{\mathrm{c}}$ & $9.55^{\mathrm{c}}$ \\
\hline
\end{tabular}

Means followed by different letters in the same column are significantly different according to the Scott-Knott test $(\mathrm{P} \leq 0.05)$.

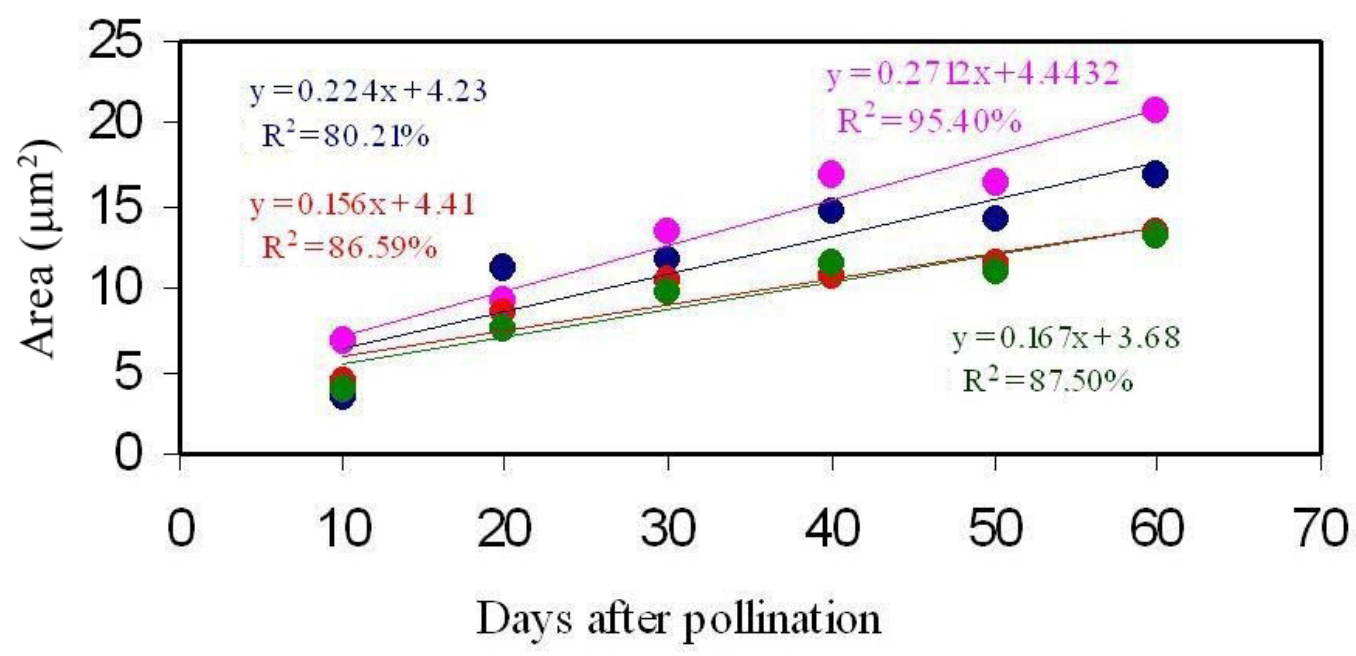

Figure 1. Regression models for area $\left(\mu \mathrm{m}^{2}\right)$ of starch granules from the cultivars Bolivia-2 (blue circles), Cateto $\mathrm{L}_{237 / 67}$ (pink circles), Opaque-2 (red circles), and QPM BR 451 (green circles) at different stages of endosperm development.

Opaque-2 and QPM BR 451 showed the smallest starch granules and lowest developmental rate (area) at all stages of grain development (Table 2 and Figure 1).

An increased area of starch granules in mature corn grains does not suggest increased grain hardness since hard- and semi-hard-endosperm cultivars showed different 
results between them, as well as those cultivars of floury endosperm (Table 2). This pattern appeared to be different from those described in the literature which reports that floury cereal grains have larger starch granules than vitreous grains (Kriz, 1987; Cagampang et al., 1985).

Considering the different grain textures, the cultivars showed differences with regard to percentage of starch. Cateto $\mathrm{L}_{237 / 67}$ (hard endosperm) and Bolivia-2 (floury endosperm) showed the largest percentages of starch in the mature grain and increase in the percentage of starch grain throughout development (Table 3 and Figure 2).

\begin{tabular}{|c|c|c|c|c|c|c|c|}
\hline \multirow[t]{2}{*}{$\overline{\text { Cultivar }}$} & \multicolumn{7}{|c|}{ Days after pollination } \\
\hline & 10 & 20 & 30 & 40 & 50 & 60 & Mean \\
\hline Bolivia -2 & $6.95^{\mathrm{b}}$ & $33.96^{\mathrm{a}}$ & $58.13^{\mathrm{a}}$ & $67.81^{\mathrm{a}}$ & $68.77^{\mathrm{a}}$ & $92.24^{\mathrm{a}}$ & $54.64^{\mathrm{a}}$ \\
\hline Cateto $\mathrm{L}_{237 / 67}$ & $13.02^{\mathrm{a}}$ & $24.80^{\mathrm{b}}$ & $48.48^{\mathrm{b}}$ & $58.61^{\mathrm{b}}$ & $62.59^{\mathrm{b}}$ & $77.27^{b}$ & $47.46^{\mathrm{b}}$ \\
\hline Opaco-2 & $8.35^{\mathrm{b}}$ & $20.74^{\circ}$ & $35.58^{\mathrm{c}}$ & $42.73^{c}$ & $52.75^{\mathrm{c}}$ & $73.47^{\circ}$ & $38.94^{\circ}$ \\
\hline QPM BR-451 & $11.42^{\mathrm{a}}$ & $21.18^{\mathrm{c}}$ & $32.64^{\circ}$ & $33.96^{\mathrm{d}}$ & $37.49^{d}$ & $65.03^{\mathrm{d}}$ & $33.62^{\mathrm{d}}$ \\
\hline
\end{tabular}

Means were obtained from four replications. Means followed by different letters in the same column are significantly different according to the Scott-Knott test $(\mathrm{P} \leq 0.05)$.

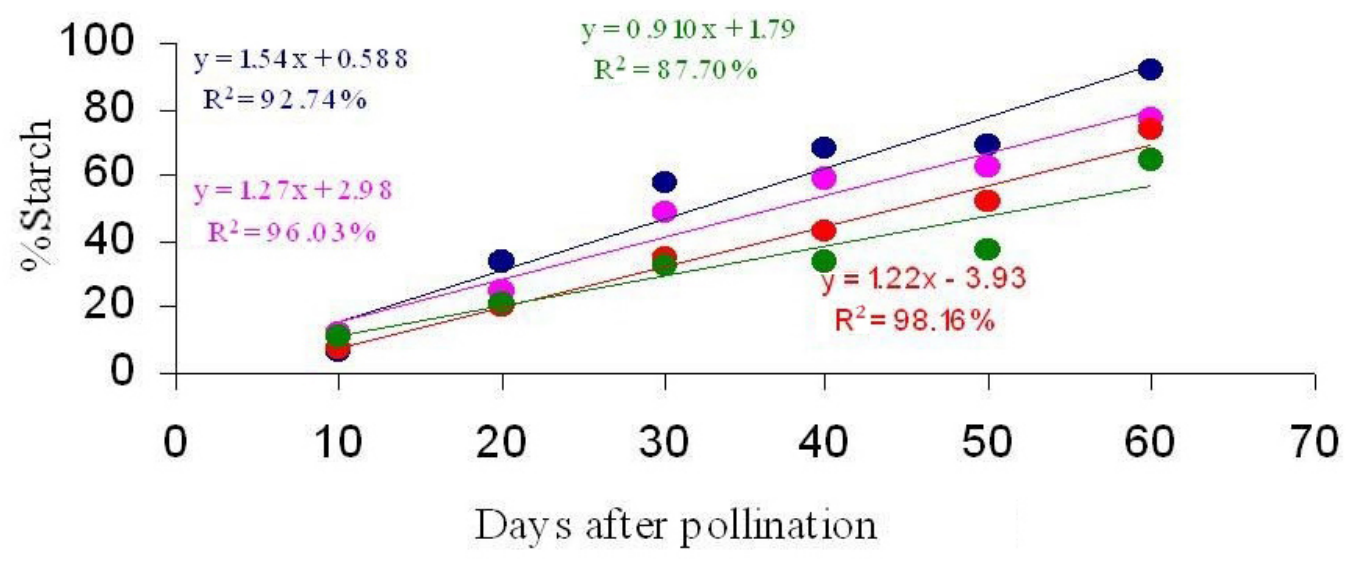

Figure 2. Regression models for percentage (\%) of starch in the cultivars Bolivia-2 (blue circles), Cateto $\mathrm{L}_{237 / 67}$ (pink circles), Opaque-2 (red circles), and QPM BR 451 (green circles) at different stages of endosperm development.

Thus, the amount of starch and the size of starch granules are not directly associated with the hardness of corn grains, as there is not a clear pattern for such characteristics in the different grain textures of the cultivars analyzed.

Hard- and semi-hard endosperm cultivars started the packing of starch granules at 30 DAP. In these cultivars, cell walls were well defined and starch granules had perfect arrangement in a polygonal format (Figure 3). 


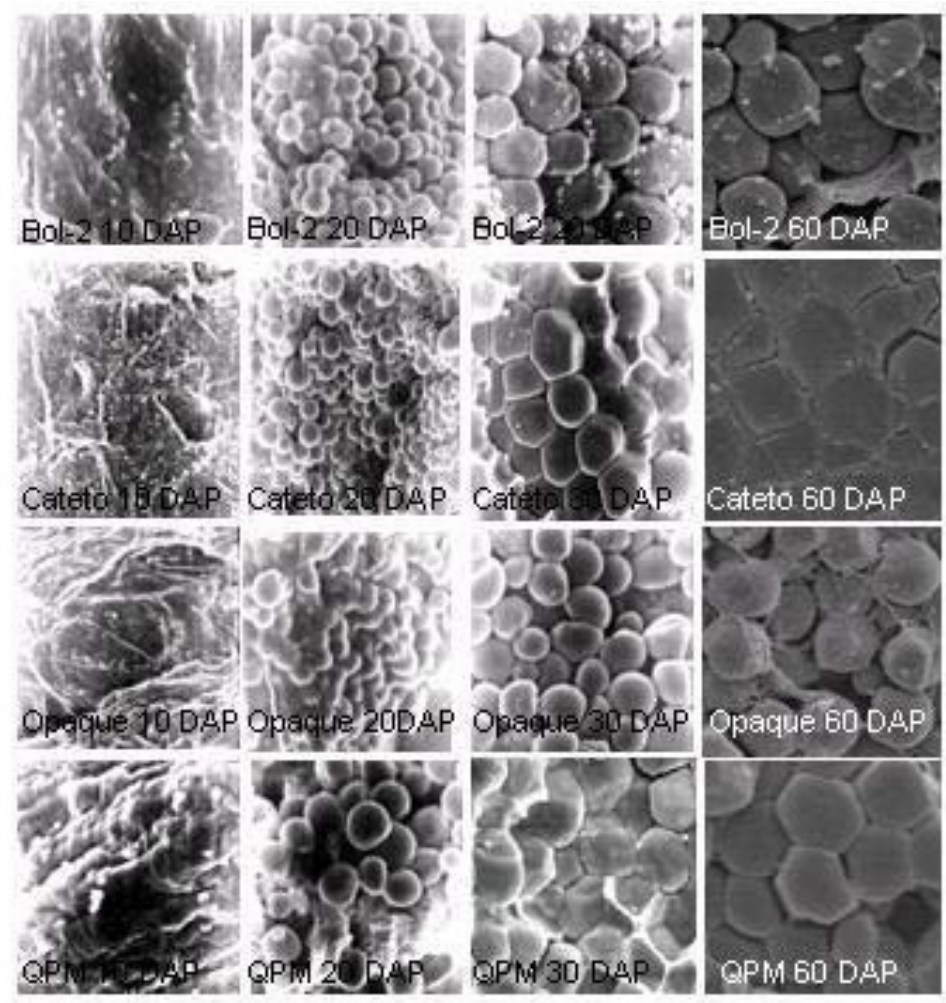

Figure 3. Scanning electron microscopy showing the starch granule arrangement in the cultivars Bolivia-2 (Bol-2), Cateto $\mathrm{L}_{237 / 67}$, Opaque-2, and QPM BR 451 at different stages of grain development. DAP = days after pollination.

Morphology and packing period of starch granules varied in the floury-endosperm cultivars, Bolivia-2 and Opaque-2, according to the development stage of the corn grain. Starch grains remained individualized and separated by large empty spaces (Opaque-2) or packed, like in Bolivia-2 (Figure 3). The packing observed in Bolivia-2 at 20 DAP was probably due to the larger size and number of starch granules in this cultivar, relative to the others (Tables 2 and 3). However, the arrangement of starch granules in Bolivia-2 was not organized, and perfect adherence between starch granules was not observed. In the same cultivar, there were round starch granules, spaced endosperm compounds and, consequently, looser packing and lower grain density (Figure 3). On the contrary, in Cateto $\mathrm{L}_{237 / 67}$ and QPM BR 451, the higher physical resistance of the grain is related to better organization of starch granules in the endosperm, where intergranular spaces are totally filled (Figures 3). In these cultivars, the presence of abundant and organized protein bodies (Figure 4) probably allowed greater adherence and better distribution of starch granules in the endosperm and, consequently, greater physical resistance of the grain. In the floury-endosperm cultivars, Bolivia-2 and Opaque-2, protein bodies were not observed (Figure 4). 


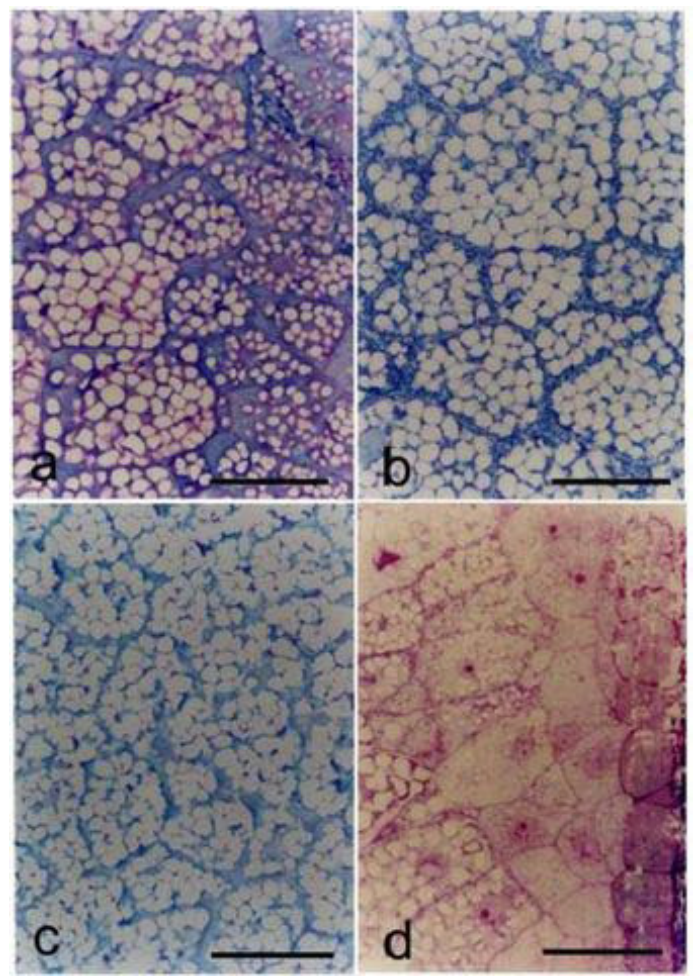

Figure 4. Light microscopy showing the presence of protein bodies in the endosperm of the cultivars Bolivia-2 (a), Cateto $\mathrm{L}_{237 / 67}$ (b), Opaco-2 (c), and QPM BR 451 (d). Bars $=10 \mu \mathrm{m}$, in all panels.

This behavior was similar to that reported in several works in which hard endosperms of normal corn grains showed high degree of compaction of their compounds, which also explains the higher density found in Cateto $\mathrm{L}_{237 / 67}$ and QPM BR 451 (Robutti et al., 1974; Wall and Bietz, 1987). In the literature, there are reports emphasizing that in corn and sorghum grains with floury endosperm starch granules are larger than in those corn grains with vitreous endosperm (Cagampang et al., 1985; Kriz, 1987). In the present study, the expected pattern was not observed, as the hard-endosperm cultivar, Cateto $\mathrm{L}_{237 / 67}$, showed the highest starch granule area, followed by the floury-endosperm cultivar, Bolivia-2 (Table 2). In the latter, packing of starch granules in the endosperm was not as perfect as that observed in hardand semi-hard endosperm cultivars, although it had larger granules and a high percentage of starch (Figure 3, Tables 2 and 3). In hard- and semi-hard endosperm cultivars, starch granules showed more organized packing and perfect adhesion, independent of their number and size (Figure 3, Tables 2 and 3). Gibbon et al. (2003) and Gibbon and Larkins (2005) reported that the strong adhesion between starch granules and absence of intergranular spaces are, from a structural point of view, the factors that contribute to the higher physical resistance of corn grains. They observed starch granules of Opaque-2 mutant and QPM cultivars and verified that, in QPM, there is strong adhesion between granules, which is not observed in Opaque-2 mutant. In the latter, the granules have a smooth round surface, making it difficult for them 
to be better arranged in the endosperm. The same authors reported that the composition of endosperm compounds is of great importance to grain texture.

The role of storage proteins is fundamental for the distribution of endosperm compounds (Simmonds et al., 1973; Abdelrahman and Hoseney, 1984; Hoseney, 1987; Glenn et al., 1991). In corn and sorghum grains of floury endosperm, protein bodies are smaller and rare (Cagampang et al., 1985; Kriz, 1987). In the present study, abundant and organized protein bodies were only observed in the hard- and semi-hard endosperm cultivars, Cateto $\mathrm{L}_{237 / 67}$ and QPM BR 451 (Figure 4). These cultivars, as already stated, also demonstrated better organization of endosperm compounds (Figure 3 ).

The electrophoretic profile of zeins varied among cultivars (Figure 5). Bolivia-2 and Cateto $\mathrm{L}_{237 / 67}$, of floury and hard endosperms, respectively, and low protein value, have low protein quality zeins $(27,22,19,16,14$, and $10 \mathrm{kDa})$. However, in Cateto $\mathrm{L}_{237 / 67}$, there is higher synthesis of these zeins (Figure 5). The high protein quality of Opaque-2 and QPM BR 451 is related to the decrease in 22-kDa zein synthesis and in 19-kDa zein synthesis (Figure 5).

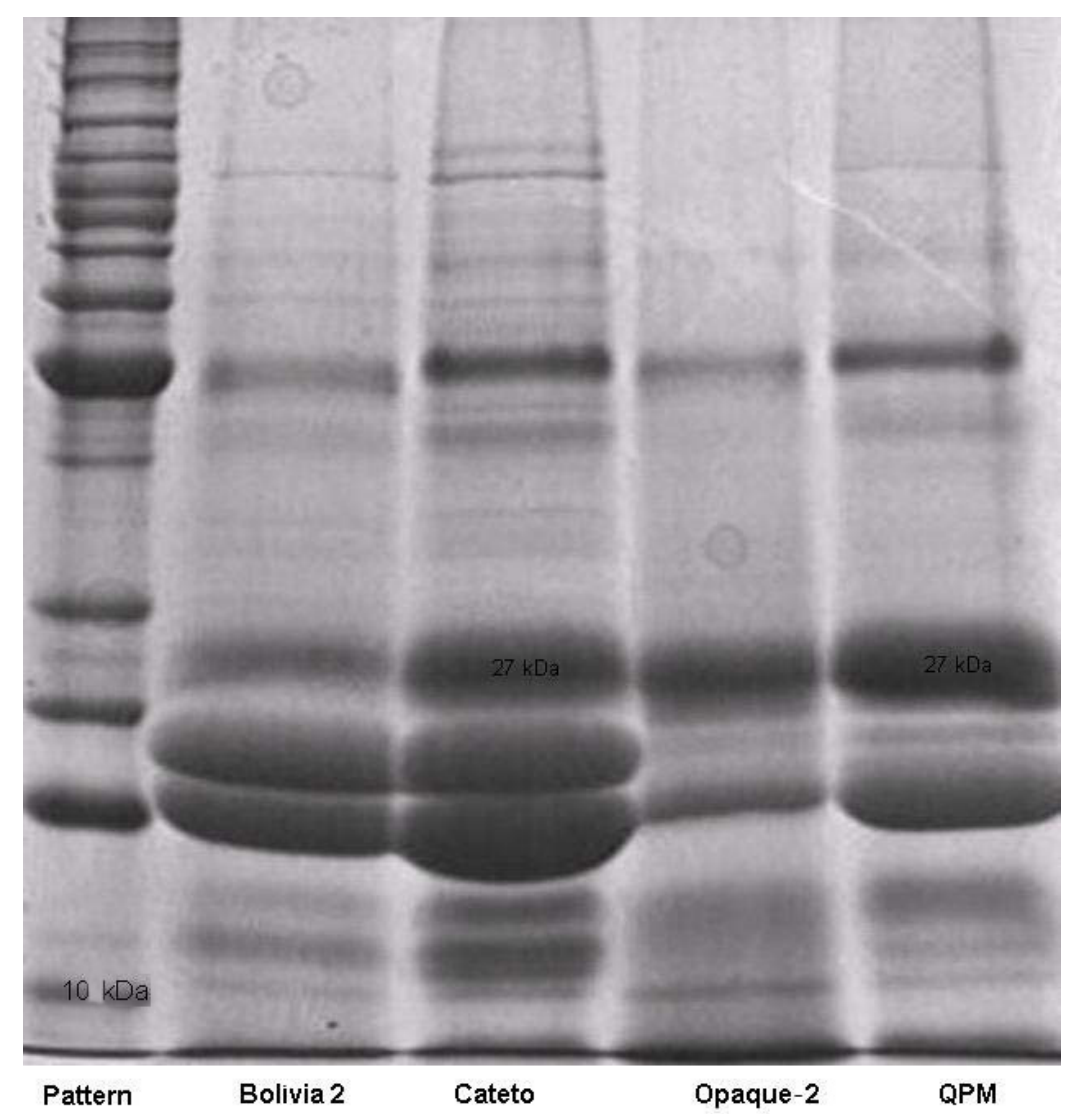

Figure 5. SDS-polyacrylamide gel electrophoresis profile of zeins from the cultivars Bolivia, Cateto $\mathrm{L}_{237 / 67}$, Opaque-2, and QPM BR 451. 
Cateto $\mathrm{L}_{237 / 67}$ and QPM BR 451, of hard and semi-hard endosperm, respectively, showed the largest percentage of total proteins (Table 1) and 27-kDa gamma-zein synthesis (Figure 5). This zein probably represents the greatest part of the storage proteins present in the grain, providing the larger number and diameter of protein bodies observed in Cateto $\mathrm{L}_{237 / 67}$ and QPM BR 451 (Figure 4). Studies have shown that hard endosperm regions of the corn grain have the highest alpha- and gamma-zein content (Paiva et al., 1991; DombrinkKurtzman and Bietz, 1993) and that 27-kDa gamma-zein plays a notable part in the formation of vitreous endosperm, as there is an increase in this zein in vitreous genotypes of QPM, when compared with those of floury Opaque-2 (Wallace et al., 1990). As gamma-zeins are located in the periphery of protein bodies and are rich in sulfurous amino acids, a larger number of disulfide bonds can lead to a higher integrity of the protein body, thus allowing better filling of intergranular spaces, as observed in the cultivars Cateto $\mathrm{L}_{237 / 67}$ and QPM BR 451.

\section{CONCLUSIONS}

For the cultivars studied, the results indicate that corn grain texture could be influenced by the distribution of starch granules, which is independent of the size and number of these granules in the endosperm.

The high number of protein bodies allows better adhesion of starch granules in hardand semi-hard endosperm cultivars.

The high synthesis of total proteins and 27-kDa gamma-zein contributes to the higher physical hardness of corn grains.

\section{ACKNOWLEDGMENTS}

The authors thank Miguel Reis (Embrapa Milho e Sorgo) for the support in the molecular biology laboratory and Dr. Eduardo Alves (Department of Plant Pathology, UFLA) for his assistance with electron microscopy. R.C. Pereira was the recipient of a CNPq scholarship. Research supported by FAPEMIG.

\section{REFERENCES}

Abdelrahman AA and Hoseney RC (1984). Basics for hardness in pearl millet, grain sorghum and corn. Cereal Chem. 61: 232-235.

Association of Official Analytical Chemistry - AOAC (2000). Methods of Analysis of the Association of Official Analytical Chemistry. 15th edn. AOAC, Arlington.

Bostwick DE, Dannenhoffer JM, Larlins BA and Or E (1995). Opaque 15, a maize mutation with properties of a defective opaque-2 modifier. Proc. Natl. Acad. Sci. 92: 1931-1935.

Cagampang GB, Greek MIB, Kirleis AW (1985). Properties of starches isolated from sorghum floury and corneous endosperm. Starch 37: 253-257.

Cagampang GB and Kirleis AW (2006). Properties of starches isolated from sorghum floury and corneous endosperm. Stärke 37: 253-257.

Coelho CM (1997). Caracterização das proteínas do endosperma do milho visando à alteração das frações que controlam qualidade nutricional. Master's thesis, Universidade Federal de Lavras, Lavras.

Correa CE, Shaver RD, Pereira MN, Lauer JG, et al. (2002). Relationship between corn vitreousness and ruminal in situ starch degradability. J. Dairy Sci. 85: 3008-3012.

Dombrink-Kurtzman MA and Bietz JA (1993). Zein composition in hard and soft endosperm of maize. Cereal Chem. 70: 105-108. 
Duvick DN (1961). Protein granules of maize endosperm cells. Cereal Chem. 38: 374-385.

Ferreira DF (2000). Análise estatística por meio do SISVAR (Sistema para Análise de Variância) para Windows versão 4.0. In: Anais da Reunião Anual da Região Brasileira da Sociedade Internacional de Biometria UFSCar, São Carlos, 225-258.

Gibbon BC and Larkins BA (2005). Molecular genetic approaches to developing quality protein maize. Trends Genet. 21: 227-233.

Gibbon BC, Wang X and Larkins BA (2003). Altered starch structure is associated with endosperm modification in quality protein maize. Proc. Natl. Acad. Sci. U. S. A. 100: 15329-15334.

Glenn GM, Younge FL and Pitts MJ (1991). Fundamental physical properties characterizing the hardness of wheat endosperm. J. Cereal Sci. 13: 179-194.

Hernandez HH and Bates LS (1969). A modified method for rapid Weatherspoon, J.H. 1970. Comparative yields of single, three-way, tryptophan analysis of maize. CIMMYT Res. Bull., Mexico.

Hoseney RC (1987). Wheat hardness. Cereal Foods World 32: 320-322.

Johnson LM, Harrison JH, Davidson D, Robutti JL, et al. (2002). Corn silage management I: effects of hybrid, maturity, and mechanical processing on chemical and physical characteristics. J. Dairy Sci. 85: 833-853.

Kniep KR and Mason SC (1989). Kernel breakage and density of normal and opaque-2 maize grain as influenced by irrigation and nitrogen. Crop Sci. 29: 158-163.

Kriz AL (1987). Evaluation of genetic factors that affect kernel hardness in maize. University of Illinois, UrbanaChampaign.

Lending CR and Larkins BA (1989). Changes in the zein composition of protein bodies during maize endosperm development. Plant Cell 1: 1011-1023.

Lopes MA (1989). Genetic and biochemical characterization of the maize mutants floury-2 and modified opaque-2. Doctoral thesis, University of Arizona, Tucson.

Mertz ET, Bates LS and Nelson OE (1964). Mutant gene that changes protein composition and increases lysine content of maize endosperm. Science 145: 279-280.

Nelson NA (1994). A photometric adaptation of Somogyi method for the determination of glucose. J. Biol. Chem. 135: 375-380.

Ortega EI and Bates LS (1983). Biochemical and agronomic studies of two modified hard endosperm opaque-2 maize (Zea mays) populations. Cereal Chem. 60: 107-111.

Paiva E, Kriz A, Peixoto MJVVD, Wallace JC, et al. (1991). Quantitation and distribution of gamma-Zein in the endosperm of maize kernels. Cereal Chem. 68: 276-279.

Pomeranz Y, Martin CR, Traylor DD and Lai FS (1984). Corn hardness determination. Cereal Chem. 61: 147-150.

Prasanna BM, Vasal SK, Kassahun B and Singh NM (2001). Quality protein maize. Curr. Sci. 81: 1308-1319.

Robutti JL, Hoseney RC and Wassom CE (1974). Modified opaque-2 corn endosperms. II. Structure viewed with a scanning electron microscope. Cereal Chem. 51: 173-179.

Simmonds DH, Barlow KK and Wrigley CW (1973). The biochemical basis of grain hardness in wheat. Cereal Chem. 50: 553-562.

Toro AA (2001). Quantificação de aminoácidos solúveis em mutantes de endosperma de milho. Master's thesis, Escola Superior de Agricultura Luiz de Queiroz, Piracicaba.

Vasal SK, Villegas E, Bjarnason M, Gelaw B, et al. (1980). Genetic modifiers and breeding strategies in developing hard endosperm opaque-2 materials. In: Improvement of quality traits of maize for grain and silage use (Pollmer WG and Phillips RH, eds.). Matinus Nijhoff, London, 37-73.

Villegas E, Vasal SK, Bjarnason M and Mertz ET (1992). Quality protein maize - what is it and how was it developed. In: Quality protein maize (Mertz ET, ed.). American Assoc. Cereal Chemistry, St. Paul, 27-48.

Wall JS and Bietz JA (1987). Differences in corn endosperm proteins in developing seeds of normal and opaque-2 corn. Cereal Chem. 64: 275-280.

Wallace JC, Lopes MA, Paiva E and Larkins BA (1990). New methods for extraction and quantitation of zeins reveal a high content of gamma-zein in modified opaque-2 maize. Plant Physiol. 92: 191-196. 